I. Reduction in mortality of persons with high blood pressure, including mild hypertension. JAMA 1979;242:2562-71.

17 Multiple risk factor intervention trial research group. Multiple risk factor intervention trial-risk factor changes and mortality results. JAMA 1982;248:1465-77

18 SHEP Cooperative Research Group. Prevention of stroke by antihypertensive drug treatment in older persons with isolated systolic hypertension. JAMA 1991;265:3255-64.

19 Dahlof B, Lindhold LH, Hansson L, Schersten B, Ekbom T, Wester P. Morbidity and mortality in the Swedish trial in old patients with hypertension (STOP-Hypertension). Lancet 1991;338:1281-5.

20 The International Prospective Primary Prevention Study in Hypertension Collaborative Group. Cardiovascular risk and risk factors in a raninternational prospective primary prevention (IPPPSH).J Hypertension 1985;3:379-92.

21 Pravastatin Multination Study Group for Cardiac Risk Patients. Effects of pravastatin in patients with serum total cholesterol levels from 5.2 to $7.8 \mathrm{mmol} /$ liter (200 to $300 \mathrm{mg} / \mathrm{dl}$ ) plus two additional atherosclerotic risk factors. Am J Cardiol 1993;72:1031-7.

22 Shepherd J, Cobbe SM, Ford I, Isles CG, Lorimer AR, Macfarlane PW, et al. Prevention of coronary heart disease with pravastatin in men with hypercholesterolemia. N Engl J Med 1995;333:1301-7.

23 Frick MH, Elo O, Haapa K, Heinonen OP, Heinsalmi P, Helo P. Helsinki heart study: primary prevention trial with gemfibrozil in middle aged men with dyslipidemia. N Engl J Med 1987;317:1237-45.
24 Committee of principal investigators. A co-operative trial in the primary prevention of ischaemic heart disease using clofibrate. Br Heart $J$ 1978;40:1069-118

25 Steering committee of the Physicians' Health Study Research Group. Final report of the aspirin component of the ongoing physicians' health study. N Engl J Med 1989;321:129-35.

26 Peto R, Gray R, Collins R, Wheatley K, Hennekens C, Jamrozik K, et al. Randomized trial of prophylactic daily aspirin in British male doctors. BMJ 1988;296:313-6.

27 Holme I, Hjermann I, Helgeland A, Leren P. The Oslo study: diet and anti-smoking advice. Prev Med 1985; 14:279-92.

28 Dorr AE, Gundersen K, Schneider R, Spencer TW, Martin WB. Colestipol hydrochloride in hypercholesterolemic patients-effect on serum cholesterol and mortality. J Chromic Dis 1978;31:5-14.

29 Lipid research clinic program. The lipid research clinic coronary primary prevention trial results. JAMA 1984;251:351-64.

30 Nieto FG, Alonso J, Chambless LE, Zhong M, Ceraso M, Romm FJ, et al. Population awareness and control of hypertension and hypercholesterolemia. The atherosclerosis risk in communities studies. Arch Intern Med 1995; 155:677-84.

31 Kine LK, Laird N, Hewitt P, Chalmers TC. Meta-analysis of empirical long-term antiarrhythmic therapy after myocardial infarction. JAMA $1989 \cdot 262: 3037-40$

(Accepted 16 April 1998)

\title{
Economic change, crime, and mortality crisis in Russia: regional analysis
}

\author{
Peder Walberg, Martin McKee, Vladimir Shkolnikov, Laurent Chenet, David A Leon
}

Department of Public Health and Caring Sciences, University of

Uppsala, S-751 85 Uppsala, Sweden Peder Walberg, medical student

European Centre on Health of Societies in

Transition, Londo School of Hygiene and Tropical Medicine, London WC1E 7HT

Martin McKee,

professor of European public health

Laurent Chenet, research fellow

David A Leon, reader in

epidemiology

Centre of

Demography and

Human Ecology,

Institute for

Economic

Forecasting, 117418

Moscow, Russian

Federation

Vladimir

Shkolnikov,

head of laboratory for

analysis and

prognosis of

population mortality

Correspondence to:

Professor McKee

m.mckee@lshtm.ac.uk

BMJ 1998;317:312-8

\begin{abstract}
Objective: To identify which aspects of socioeconomic change were associated with the steep decline in life expectancy in Russia between 1990 and 1994.

Design: Regression analysis of regional data, with percentage fall in male life expectancy as dependent variable and a range of socioeconomic measures reflecting transition, change in income, inequity, and social cohesion as independent variables.

Determination of contribution of deaths from major causes and in each age group to changes in both male and female life expectancy at birth in regions with the smallest and largest declines.
\end{abstract}

Setting: Regions (oblasts) of European Russia (excluding Siberia and those in the Caucasus affected by the Chechen war).

Subjects: The population of European Russia.

Results: The fall in life expectancy at birth varied widely between regions, with declines for men and women highly correlated. The regions with the largest falls were predominantly urban, with high rates of labour turnover, large increases in recorded crime, and a higher average but unequal distribution of household income. For both men and women increasing rates of death between the ages of 30 and 60 years accounted for most of the fall in life expectancy, with the greatest contributions being from conditions directly or indirectly associated with heavy alcohol consumption.

Conclusions: The decline in life expectancy in Russia in the 1990s cannot be attributed simply to

impoverishment. Instead, the impact of social and economic transition, exacerbated by a lack of social cohesion, seems to have played a major part. The evidence that alcohol is an important proximate cause of premature death in Russia is strengthened.

\section{Introduction}

The scale of the health crisis facing the Russian people in recent years is now well recognised. After a period of steady improvement after the second world war, life expectancy at birth began to lag behind that in the West in the mid-1960s. A substantial improvement in 1985, coinciding with a major campaign to reduce alcohol consumption, ${ }^{12}$ was rapidly reversed and has fallen even further since the collapse of the Soviet Union, ${ }^{3}$ with life expectancy at birth falling by over 5 years between 1990 and 1994. We have previously shown that these changes cannot be attributed to artefact.

The decline in Russians' life expectancy in the 1990s is clearly driven by profound economic, political, and social changes. There is also considerable evidence that alcohol has played a major part. ${ }^{4}$ The nature of these relations, however, remains unclear. In particular, the relative importance of impoverishment and of the effects of rapid social and economic transition requires elucidation, as some argue that little can be done in the absence of policies to deal with the economic decline that has occurred in the 1990s whereas others have suggested that the effect of rapid change is more important. ${ }^{5}$

The nature of the social and economic transition in Russia has not been uniform, with some regions affected much more than others. There are also large differences in mortality within the regions of Russia. ${ }^{6}$ We explored the nature of the links between economic factors and mortality by taking advantage of this regional diversity. In particular, we examined whether it was possible to distinguish the effects of impoverishment from those resulting from the pace of transition. If the increase in mortality has been a result of impoverishment we would expect the greatest falls in life expectancy in regions experiencing the largest falls in average income; if it has 
been a result of the rapid pace of transition we would expect the greatest falls in regions experiencing the greatest disruption in patterns of employment.

\section{Methods}

All data were obtained from Goskomstat, the Russian state statistics committee, which collects data disaggregated to each of the 71 regions and two major cities (Moscow and St Petersburg) existing before 1992 in the Russian Federation (subsequently some regions were split to produce a total of 88 regions, but the earlier boundaries have been used to maintain consistency). Data on deaths by age and cause are compiled from returns by registration offices (ZAGs) in each region. Data on population have been derived by Goskomstat from returns in the 1989 census with allowance for demographic change and estimated migration. Numbers of deaths in each region were obtained by sex, by 5 year age band (except for those aged under 5 , for whom numbers of deaths by individual year were available), and by cause of death (with the Soviet classification that consists of 175 primary diagnostic categories). Causes of death were aggregated into nine broad categories (table 1). Corresponding mid-year population estimates were used as denominators.

We sought data that would capture four broad categories: change in income; equity; transition; and social cohesion. These were derived from a regular series of surveys undertaken by Goskomstat, with a random sample of about 50000 households drawn from all regions. Trends in average household income were adjusted for changes in the consumer price index, which was available for each region. Equity was measured by the Robin Hood index. ${ }^{7}$ This approximates to the share of total income that would have to be transferred from those with above average income to those below average to achieve an equal distribution of income. We chose this index rather than the more usual Gini coefficient because the Gini coefficient is more susceptible to the quality of data at the extremes of the distribution. The two measures were, however, highly correlated $(r=0.915)$. Data on distribution of income were available only for 1994.

Drawing on work by Cornia, we calculated an explanatory variable-"labour turnover"-which is the sum of job gains and losses in medium and large enterprises in 1993 and 1994, the years for which data were available, as a percentage of the average employment in these enterprises. This variable can be considered as a measure of "transition" or "labour market shock." Earlier work showed that this variable was strongly associated with increases in mortality in Russian regions (G A Cornia, UNU/WIDER project meeting on economic shocks, social stress, and the demographic impact, Helsinki, April 1997). ${ }^{8}$

Trends in reported crimes were used as an indirect measure of civic cohesion; we assumed that high levels of crime suggest lack of cohesion. This is consistent with a growing body of evidence from elsewhere suggesting that crime can be a proxy measure of social cohesion or social capital. ${ }^{9}$ Ideally, we would have included data on alcohol consumption. Unfortunately, although data on sales are available, they are known to be unreliable, especially since 1987 when illicit production increased greatly. ${ }^{10}$
Table 1 Definition of categories of cause of death used in analyses of change in life expectancy in Russia

\begin{tabular}{|c|c|c|}
\hline \multirow{2}{*}{ Category } & Code (Soviet classification) & IDC-9 equivalent \\
\hline & $84-97,100-102$ & $410-429,440-459$ \\
\hline Cerebrovascular diseases & 98,99 & $430-438$ \\
\hline Respiratory cancer & 53 & 162 \\
\hline Other neoplasms & $45-52,54-67$ & 140-161, 163-239 \\
\hline Respiratory diseases & $103-114$ & $460-519$ \\
\hline Infectious diseases & $1-44$ & $1-139$ \\
\hline Accidents $^{*}$ & 160-162, 164-175 & E810-E858, E861-E989 \\
\hline Alcohol related diseases $\dagger$ & $73,75,122,123,126,163$ & $\begin{array}{l}291,303,571.0-571.3,571.5-571.6 \\
577, \text { E860 }\end{array}$ \\
\hline Otherł & $\begin{array}{l}68-72,74,76-83,115-121,124 \\
125,127-159\end{array}$ & $\begin{array}{l}240-290,292-302,304-380,520-570 \\
571.4,571.8-576,578,579,580-799\end{array}$ \\
\hline \multicolumn{3}{|c|}{$\begin{array}{l}\text { *Includes accidents, poisonings, homicide, suicide, but does not include accidental alcohol poisoning. } \\
\text { †Includes alcohol psychosis, alcohol dependence syndrome, liver cirrhosis, disease of pancreas, accidental } \\
\text { alcohol poisoning. } \\
\text { łlncludes endocrine, mental, digestive, urogenital, congenital, perinatal, pregnancy complications; skin } \\
\text { conditions—cutaneous and musculoskeletal; ill defined disease. }\end{array}$} \\
\hline \multicolumn{3}{|c|}{$\begin{array}{l}\text { Table } 2 \text { Regions categorised by change in male life expectancy at birth, Russia, } \\
\text { 1990-4 }\end{array}$} \\
\hline Fourths & \multicolumn{2}{|l|}{ Regions } \\
\hline 1 (smallest decrease) & \multicolumn{2}{|c|}{$\begin{array}{l}\text { Astrakhan, Belgorod, Chuvashia, Kalmykia, Krasnodar, Kursk, Modovia, Penza, } \\
\text { Stavropol, Tambov, Tatarstan, Ulyanovsk, Voronezh }\end{array}$} \\
\hline 2 & \multicolumn{2}{|c|}{$\begin{array}{l}\text { Basjkorstan Bryansk Kaluga, Kirov, Kostroma, Kurgan, Lipetsk, Marij El, Rostov, } \\
\text { Volgograd, Orel, Samara, Saratov }\end{array}$} \\
\hline 3 & \multicolumn{2}{|c|}{$\begin{array}{l}\text { Chelyabinsk, Ivanovo, Kaliningrad, Nizhniy Novgorod, Novgorod, Orenburg, Ryazan, } \\
\text { Smolensk, Sverdlovsk, Vladimir, Vologda, Yaroslav }\end{array}$} \\
\hline 4 (largest decrease) & \multicolumn{2}{|c|}{$\begin{array}{l}\text { Archangelsk, Karelia, Komi, Leningrad, Moscow City, Moscow, Murmansk, Perm, } \\
\text { Pskov, St Petersburg City, Tula, Tver, Udmurtia }\end{array}$} \\
\hline
\end{tabular}

For the purposes of the analysis, data from Siberia and from four predominantly Muslim regions in southern Russia were excluded, leaving the 52 more homogenous regions of European Russia. Siberia was excluded because there are major distortions in the local economy to take account of the much higher cost of living. For example, the median monthly household income in European Russia in 1990 was 194 roubles (£180) compared with 221 in Siberia (Mann-Whitney $\mathrm{P}=0.0009$ ). More importantly, there were substantial subsidies that changed rapidly during this period, the effects of which are difficult to identify. Data from the excluded regions in southern Russia are also problematic for several reasons. There are few data from Chechenia because of the war, and the neighbouring regions havebeenaffected substantiallybyrefugeemovements. In addition, historically these regions exhibit a pattern of health that is much more like that seen in the countries of Transcaucasia (Armenia, Georgia, and Azerbaijan) than in Russia. These regions are also believed to underregister deaths in elderly people.

\section{Analysis}

The analysis focused on change in male life expectancy at birth between 1990 (the first year for which detailed regional data were available to us) and 1994 (the year when it reached its lowest level in nearly all regions). Male life expectancy was used as it has shown the greatest fall. Across regions, however, both the absolute levels and the subsequent relative deterioration in life expectancy at birth for men and women are highly correlated ( $r=0.796$ and $r=0.892$, respectively).

Factors associated with the change in life expectancy were explored by using multiple linear regression (SPSS), with the percentage fall in life expectancy at birth between 1990 and 1994 as the 
Table 3 Variables used in analysis and their univariate association with proportional fall in male life expectancy at birth, Russia, 1990-4

\begin{tabular}{lc} 
Variables & Median (interquartile range) \\
\hline Fall in male life expectancy at birth 1990-4 (\%) & $9.3(7.8-10.9)$ \\
\hline Life expectancy in 1990 & $64.05(63.53-64.78)$ \\
\hline Mean household income (roubles) in 1990* & $194.3(184.4-204.4)$ \\
\hline Fall in income, adjusted for regional consumer price index (\%) & $14.7(0.7-28.8)$ \\
\hline Robin Hood index (1994) & $21.5(20.5-22.7)$ \\
\hline $\begin{array}{l}\text { Labour turnover (job gains and losses per } 1000 \text { employees) in } \\
\quad \text { large and medium enterprises }\end{array}$ & $44.6(40.4-51.2)$ \\
\hline Industrial production index (1990=100) & $51(46-61)$ \\
\hline Reported crime per 100000 people, 1990 & $1123(952-1322)$ \\
\hline Crime increase (\%) & $48.6(31.2-63.0)$ \\
\hline${ }^{*}$ One rouble=93p.
\end{tabular}

Table 4 Correlation matrix of variables used in analysis

\begin{tabular}{|c|c|c|c|c|c|c|c|}
\hline Variable & $\begin{array}{c}\text { Income } \\
1990\end{array}$ & $\begin{array}{c}\text { Income } \\
\text { fall }\end{array}$ & $\begin{array}{l}\text { Robin Hood } \\
\text { index } \\
(1994)\end{array}$ & $\begin{array}{l}\text { Labour } \\
\text { turnover }\end{array}$ & $\begin{array}{l}\text { Industrial } \\
\text { production } \\
\text { fall }\end{array}$ & $\begin{array}{c}\text { Crime } \\
1990\end{array}$ & $\begin{array}{c}\text { Crime } \\
\text { increase }\end{array}$ \\
\hline Fall in life expectancy & $0.498^{\text {** }}$ & $-0.316^{*}$ & -0.230 & $0.651^{\star \star * *}$ & -0.071 & $0.318^{*}$ & $0.375^{\star \star \star}$ \\
\hline Crime increase & 0.177 & 0.002 & $-0.441^{\star \star *}$ & 0.115 & $-0.235^{\star}$ & -0.163 & - \\
\hline Crime 1990 & 0.104 & -0.047 & 0.058 & $0.615^{\star \star \star}$ & 0.033 & - & - \\
\hline $\begin{array}{l}\text { Industrial production } \\
\text { index }\end{array}$ & 0.087 & -0.199 & 0.101 & 0.169 & - & - & - \\
\hline Labour turnover & $0.417^{* \star *}$ & $-0.307^{\star}$ & -0.089 & - & - & - & - \\
\hline $\begin{array}{l}\text { Robin Hood index } \\
\text { (1994) }\end{array}$ & 0.064 & 0.063 & - & - & - & - & - \\
\hline Income fall & -0.167 & - & - & - & - & - & - \\
\hline
\end{tabular}

Table 5 Multivariate analysis of association with fall in male life expectancy at birth, Russia, 1990-4

\begin{tabular}{lccc} 
Variable & $\begin{array}{c}\text { Cumulative } \\
\text { adjusted } r^{2}\end{array}$ & Adjusted $\boldsymbol{\beta}$ (SE) & Univariate $\boldsymbol{\beta}$ (SE) \\
\hline Labour turnover & 0.423 & $0.147(0.030)^{\star \star *}$ & $0.183(0.029)^{\star \star *}$ \\
\hline Crime increase $(\%)$ & 0.514 & $0.029(0.010)^{\star *}$ & $0.039(0.014)^{\star *}$ \\
\hline Mean household income (roubles) 1990 & 0.558 & $0.019(0.008)^{\star}$ & $0.041(0.01)^{\star *}$ \\
\hline
\end{tabular}

${ }^{\star} \mathrm{P}<0.05 ;{ }^{*} \mathrm{P}<0.01 ;{ }^{* *}{ }^{*} \mathrm{P}<0.001$.

Table 6 Multivariate analysis of association with fall in male life expectancy at birth, Russia, 1990-4, excluding crime variables

\begin{tabular}{lcc} 
Variable & Cumulative adjusted $r^{2}$ & Adjusted $\boldsymbol{\beta}$ (SE) \\
\hline $\begin{array}{l}\text { Labour turnover (job gains and losses/average } \\
\text { employment) in large and medium enterprises }\end{array}$ & 0.423 & $0.153(0.029)^{\star \star \star}$ \\
\hline Robin Hood index & 0.499 & $-0.376(0.118)^{\star \star}$ \\
\hline Mean household income (roubles) in 1990 & 0.557 & $0.023(0.008)^{\star \star}$ \\
\hline
\end{tabular}

${ }^{* *} \mathrm{P}<0.01 ;{ }^{* * *} \mathrm{P}<0.001$

dependent variable, forward entry of independent variables, and a probability of entry of 0.05 .

The second part of the analysis sought to determine the proximate reasons for the different levels of deterioration in life expectancy and, specifically, to obtain some indication of the contribution of alcohol to the differences in performance between regions. Regions were ranked in terms of the percentage fall in male life expectancy at birth between 1990 and 1994 and divided into fourths (table 2). To permit comparison of males and females the same allocation of regions to fourths was used for analyses of data for both sexes. The lowest fourth signifies the regions that experienced the smallest decrease in male life expectancy at birth during this period, and the highest fourth the regions with the greatest falls. The contribution that each death from each diagnostic category and

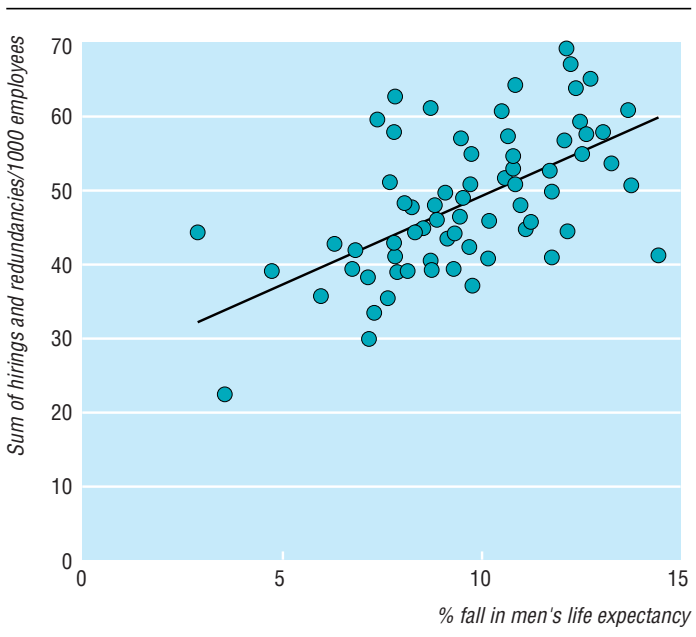

Fig 1 Association between labour turnover in 1993-4 and fall in life expectancy in 1990-4

age group had made to the overall decline was then determined for the lowest and highest fourths by using the method devised by Pollard. ${ }^{11}$

\section{Results}

The definitions of the variables analysed are in table 3 . Table 4 shows that the fall in life expectancy was most closely correlated with labour turnover (figure 1), followed by income in 1990 (with the wealthiest regions experiencing the greatest falls in life expectancy), and then by the increase in crime. The other significant correlations indicate that the fall in life expectancy was also greatest in regions where crime levels were highest in 1990, which experienced the smallest reductions in income, and which in 1994 were the most unequal. The matrix also suggests that the increase in crime was greatest in regions that were the most unequal.

The results of the multivariate analysis are shown in table 5. Labour turnover, percentage increase in crime, and mean household income were included in the model, together explaining almost $56 \%$ of the observed regional variation in the change in life expectancy. The regression coefficients, adjusted for the other variables in the model, were about two thirds those in the univariate analyses for labour turnover and crime increase but about half of that for income.

As it seemed plausible that some of the factors affecting health might also be affecting crime rates, the regression was repeated without data on crime. The results are shown in table 6 . In this case, the Robin Hood index was included in the model.

Turning to the second part of the analysis, between 1990 and 1994 life expectancy in men dropped by 8.6 years in the highest fourth and by 4.97 years in the lowest fourth. The corresponding figures for women were, as expected, rather lower at 4.12 and 2.55 years, respectively. It should be noted that in 1995 nearly all Russian regions experienced a slight improvement, although a few in Siberia have experienced further falls. There was a clear geographical pattern, with the greatest falls in the north and the smallest in the south (figure 2). Many of the regions experiencing the greatest falls were also the most urbanised. There were also several regions in other parts of Russia that experienced particularly 


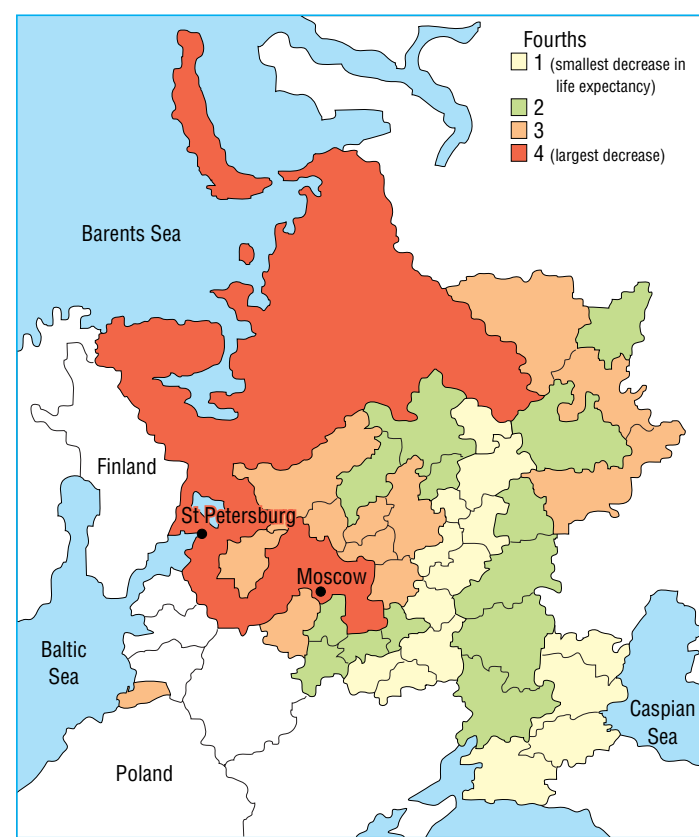

Fig 2 European Russia, showing regional pattern of change in male life expectancy at birth between 1990 and 1994
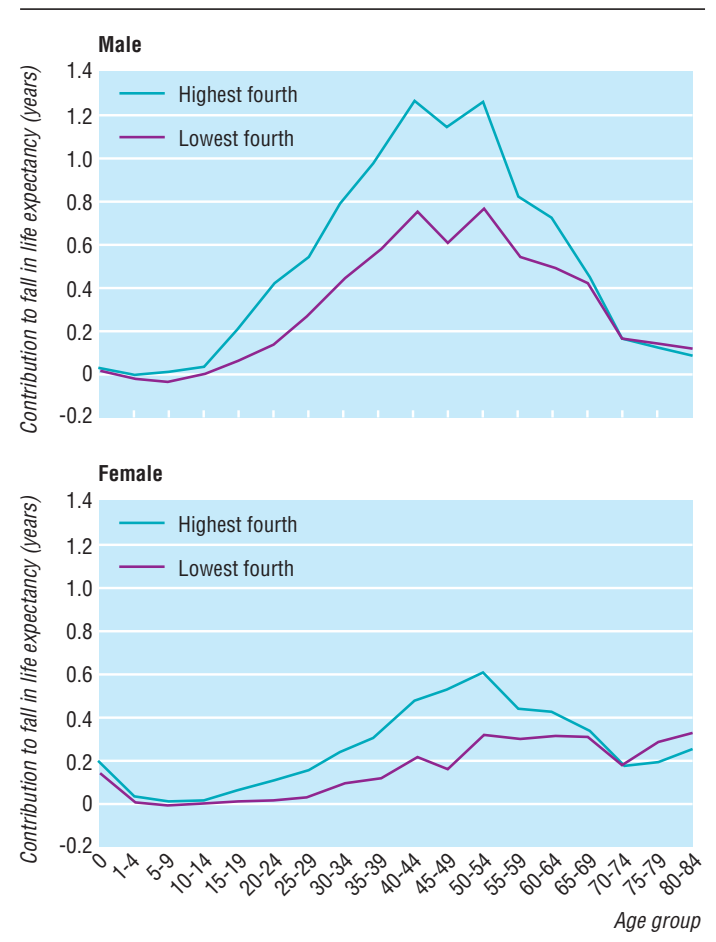

Fig 3 Contribution of deaths in each age band to fall in male life expectancy at birth in highest and lowest fourths of distribution of percentage fall in life expectancy

small declines. These included some, such as Tatarstan, with large Muslim populations.

For both sexes and in all regions deaths in the 30 to 60 year age group contributed most to the fall in life expectancy; these deaths were also the most important contributors to the worse performance of regions in the highest fourth (figure 3). Among men in the highest fourth, deaths between 40 and 54 years accounted for $40 \%$ of the total decline in life expectancy. Deaths among children of both sexes made little contribution to the change, nor did deaths among elderly men, although the proportion of those surviving to old age was relatively small because of the high level of premature mortality. Deaths among elderly women, especially in the lowest fourth, made a greater relative contribution.

Examination by cause of death (table 7) showed that for men the 3.6 year difference between the fourths was explained largely by accidents ( 1.67 years), alcohol related causes ( 0.84 years), and cardiovascular disease ( 0.52 years). There were smaller contributions from respiratory and cerebrovascular diseases, and deaths from cancer made a negligible contribution to both the overall fall and the difference between fourths.

Table 8 shows that for women the results were similar, with the 1.57 year difference largely accounted for by deaths from accidents ( 0.65 years), alcohol related causes ( 0.41 years), and cardiovascular disease ( 0.37 years).

\section{Discussion}

\section{Limitations}

Before we can discuss the implications of this study it is necessary to explore its limitations. We could not undertake a detailed nationwide validation of the quality of data on either death registration or the explanatory variables used. The quality of recording deaths in Russia has, however, been examined in detail by using standard demographic techniques. ${ }^{42} 13$ These analyses can be summarised as showing that the quality of data is generally good, although there are some concerns about deaths among infants, reflecting the definition of infant deaths used in Russia, and among elderly people. In the present context such concerns are less relevant as deaths in these age groups have had a relatively small role in the observed changes. There is inevitably rather more concern about the quality of the explanatory variables examined, reflecting both the culture of distortion of certain statistics at local level during the Soviet period and the increased difficulty of collecting such information in the more liberal situation pertaining since 1991. ${ }^{14}$ In particular, sampling methods may not produce entirely representative samples, missing the very poor and very rich. For example, the Gini coefficients, which are likely to be most affected by such problems, seemed surprisingly small in view of the obvious inequality seen in major Russian cities, hence our choice of the Robin Hood index. The figures for labour turnover are limited to large and medium enterprises and fail to capture job creation in small businesses or the informal economy. It would be surprising if the figures for recorded crime were not an underestimate of the true rates, although such problems are not confined to Russia. Although the data obtained for this study are much more representative and comprehensive than those available previously, the regression results must, none the less, be treated with some caution.

A further limitation is that in this paper we have focused primarily on determinants of the change in life expectancy in men, recognising that in situations of acute social and economic transition they, especially if single, are more vulnerable than women. ${ }^{15}$

\section{A possible model?}

With these caveats, the analyses do shed some light on the factors underlying the decrease in life expectancy 
Table 7 Contribution (in years) of causes of death to change in male life expectancy at birth in first and fourth fourths between 1990 and 1994

\begin{tabular}{|c|c|c|c|c|c|c|c|c|c|c|}
\hline $\begin{array}{l}\text { Age } \\
\text { (years) }\end{array}$ & Cardiovascular & Cerebrovascular & $\begin{array}{l}\text { Respiratory } \\
\text { cancer }\end{array}$ & $\begin{array}{c}\text { Other } \\
\text { neoplasms }\end{array}$ & $\begin{array}{l}\text { Infectious } \\
\text { diseases }\end{array}$ & $\begin{array}{c}\text { Respiratory } \\
\text { diseases }\end{array}$ & Accidents & $\begin{array}{l}\text { Alcohol } \\
\text { related }\end{array}$ & Other & Total \\
\hline \multicolumn{11}{|c|}{ Lowest fourth (smallest decrease in life expectancy) } \\
\hline 0 & -0.003 & 0 & 0 & 0 & -0.022 & -0.017 & -0.002 & -0.001 & 0.103 & 0.060 \\
\hline $1-14$ & -0.002 & 0.001 & 0 & -0.026 & -0.004 & -0.040 & -0.026 & 0.000 & -0.012 & -0.107 \\
\hline $15-34$ & 0.143 & 0.008 & -0.002 & 0.017 & 0.018 & 0.020 & 0.448 & 0.106 & 0.100 & 0.715 \\
\hline $35-64$ & 1.093 & 0.278 & -0.012 & 0.036 & 0.117 & 0.215 & 0.858 & 0.467 & 0.403 & 2.361 \\
\hline$\geqslant 65$ & 0.319 & 0.108 & 0.014 & 0.031 & 0.001 & 0.037 & 0.043 & 0.015 & 0.140 & 0.389 \\
\hline All $(\%)$ & $1.550(31)$ & $0.393(8)$ & 0 & $0.057(1)$ & $0.110(2)$ & $0.215(4)$ & $1.321(27)$ & $0.588(12)$ & $0.735(15)$ & $4.968(100)$ \\
\hline \multicolumn{11}{|c|}{ Highest fourth (largest decrease in life expectancy) } \\
\hline 0 & 0.001 & 0.001 & 0 & -0.002 & -0.003 & -0.031 & 0.016 & 0 & -0.040 & -0.058 \\
\hline $1-14$ & 0.001 & 0 & 0.001 & -0.016 & 0.004 & -0.013 & 0.064 & 0 & 0.014 & 0.053 \\
\hline $15-34$ & 0.143 & 0.011 & -0.001 & -0.009 & 0.042 & 0.062 & 1.164 & 0.303 & 0.171 & 1.743 \\
\hline $35-64$ & 1.580 & 0.344 & -0.024 & 0.023 & 0.181 & 0.467 & 1.671 & 1.095 & 0.652 & 4.410 \\
\hline$\geqslant 65$ & 0.341 & 0.162 & 0.003 & 0 & 0.006 & 0.051 & 0.072 & 0.030 & 0.061 & 0.386 \\
\hline All $(\%)$ & $2.066(24)$ & $0.517(6)$ & $-0.021(0)$ & $-0.005(0)$ & $0.230(3)$ & $0.537(6)$ & 2.989 (35) & $1.428(17)$ & $0.858(10)$ & $8.599(100)$ \\
\hline
\end{tabular}

Table 8 Contribution (in years) of causes of death to change in female life expectancy at birth in first and fourth fourths between 1990 and 1994

\begin{tabular}{|c|c|c|c|c|c|c|c|c|c|c|}
\hline $\begin{array}{l}\text { Age } \\
\text { (years) }\end{array}$ & Cardiovascular & Cerebrovascular & $\begin{array}{l}\text { Respiratory } \\
\text { cancer }\end{array}$ & $\begin{array}{c}\text { Other } \\
\text { neoplasms }\end{array}$ & $\begin{array}{l}\text { Infectious } \\
\text { diseases }\end{array}$ & $\begin{array}{c}\text { Respiratory } \\
\text { diseases }\end{array}$ & Accidents & $\begin{array}{l}\text { Alcohol } \\
\text { related }\end{array}$ & Other & Total \\
\hline \multicolumn{11}{|c|}{ Lowest fourth (smallest decrease in life expectancy) } \\
\hline 0 & 0 & 0.001 & 0 & 0.004 & 0.019 & -0.006 & 0.007 & 0.001 & 0.215 & 0.240 \\
\hline $1-14$ & -0.003 & -0.001 & -0.001 & -0.016 & -0.008 & -0.023 & 0.021 & -0.001 & -0.002 & -0.031 \\
\hline $15-34$ & 0.021 & -0.004 & -0.004 & -0.018 & 0.003 & -0.009 & 0.081 & 0.023 & 0.000 & 0.072 \\
\hline $35-64$ & 0.487 & 0.146 & 0.005 & 0.036 & 0.017 & 0.018 & 0.249 & 0.218 & 0.161 & 0.850 \\
\hline$\geqslant 65$ & 0.341 & 0.143 & 0.004 & 0.031 & 0.001 & -0.026 & 0.020 & 0.013 & 0.387 & 0.573 \\
\hline All (\%) & $0.846(33)$ & $0.285(11)$ & $0.004(0)$ & $0.037(1)$ & $0.032(1)$ & $-0.046(-2)$ & 0.377 (15) & $0.254(10)$ & $0.762(30)$ & $2.550(100)$ \\
\hline \multicolumn{11}{|c|}{ Highest fourth (largest decrease in life expectancy) } \\
\hline 0 & 0 & 0.001 & 0 & -0.002 & 0.009 & -0.001 & 0.013 & 0 & 0.021 & 0.042 \\
\hline $1-14$ & 0.001 & 0 & 0 & -0.013 & 0.004 & -0.010 & 0.070 & -0.001 & 0.005 & 0.054 \\
\hline 15-34 & 0.051 & 0.001 & 0 & -0.008 & 0.017 & 0.023 & 0.332 & 0.083 & 0.040 & 0.486 \\
\hline $35-64$ & 0.792 & 0.269 & -0.002 & 0.015 & 0.058 & 0.124 & 0.578 & 0.562 & 0.279 & 1.882 \\
\hline$\geqslant 65$ & 0.373 & 0.244 & -0.006 & -0.011 & 0.007 & 0.008 & 0.040 & 0.020 & 0.143 & 0.444 \\
\hline All (\%) & $1.215(29)$ & $0.514(12)$ & $-0.008(0)$ & $-0.021(0)$ & $0.095(2)$ & $0.144(3)$ & $1.033(25)$ & $0.663(16)$ & $0.487(12)$ & $4.123(100)$ \\
\hline
\end{tabular}

in Russia since 1990, which is still poorly understood and highly controversial. Those regions of European Russia that have suffered most since 1990 are the urban areas that have been exposed most to social and economic transition and which, while experiencing the greatest increases in average income, have become the most unequal and have also had the greatest increases in crime.

With caution we can construct a possible model that will explain the observed relations and that could be tested in other situations (figure 4). In this putative model, what we have termed "transition" (measured by turnover of the labour force) seems to be a driving force, exacerbated by inequality. These factors are both associ-

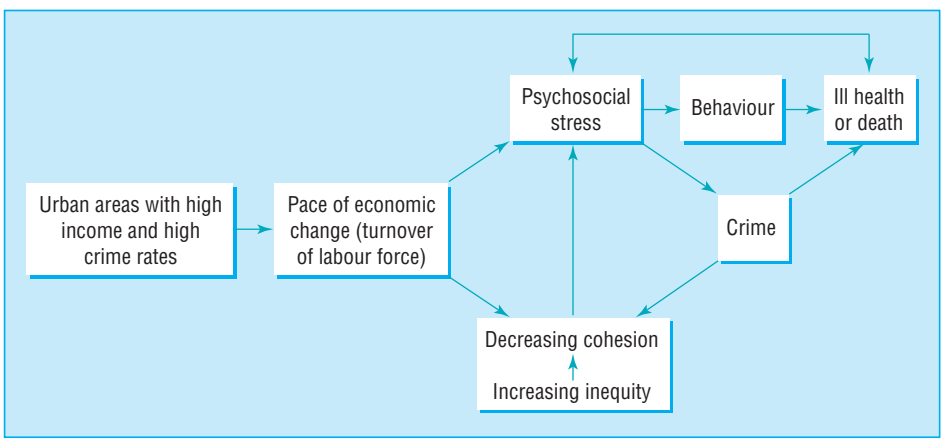

Fig 4 Putative model of associations among transition, cohesion, and health ated with an increase in crime, but the extent of the associations is a function of various factors, one of which is social cohesion, in itself a function of inequality. In this model we argue that whereas social cohesion will ameliorate the effects of transition on crime and health, the existence of factors that act on health over the entire life course means that the association with crime is likely to be more direct. Consequently, for the present purposes, the rise in crime can be thought of as an, albeit imperfect, proxy for a lack of social cohesion. In summary, acute transition in the presence of low social cohesion and inequality leads to a decline in health at least in part mediated by behavioural changes, most notably alcohol consumption in the case of Russia.

There are, of course, likely to be other associations, such as the direct effect of crime on mortality through homicide. Although homicide rates in Russia are high, they account for only $1.2 \%$ of all reported crimes, although they may account for a considerable proportion of all deaths among adults. Many of these relations are also likely to be two directional, and, in Russia at least, the high levels of organised crime may also feed back into economic decline and thus inequality and a loss of social cohesion as they inhibit the growth of small enterprises. ${ }^{16}$ For example, in this dataset the crime rate in 1990 could explain $40 \%$ of the labour turnover in 1994. 


\section{Other explanations}

These analyses also provide an opportunity to test some of the other hypotheses that have been proposed to explain the decline in health in eastern Europe. ${ }^{17}$ These include impoverishment, environmental pollution, deterioration in health services, and psychosocial stress arising from the pace of change.

Impoverishment-The finding that the greatest declines in life expectancy are in those regions that were the wealthiest in 1990 and have subsequently experienced the smallest declines in household income is contrary to the suggestion that the fall in life expectancy can be attributed to impoverishment. A possible explanation is that regions with high average incomes are also characterised by other features that are responsible for the decline in life expectancy, but we cannot explore this further with the data available to us. It is well known, for example, that in Russia higher salaries were used to compensate for hard manual work or for difficult climatic conditions (so called regional coefficients). We have excluded Siberia, however, which contains most of the regions so affected, although the same peculiar pattern is characteristic of some regions in the north of European Russia with predominantly primary industries (mining, oil and gas, timber, etc). Although this issue requires further elucidation, obviously it is not sufficient to depend solely on economic growth to bring about an improvement in health.

Environment and health services-Neither the causes of death contributing to the decline nor the geographical distribution are consistent with a causal role for environmental pollution, and this has been declining anyway because of the collapse of much heavy industry. Although there can be little doubt that the health service has suffered in many ways since the break up of the Soviet Union, ${ }^{18}$ the age groups affected most are those with least contact with health services, with people dying of causes that are relatively insensitive to medical care.

Pace of change-The many benefits that were associated with work in certain enterprises in the Soviet bloc, such as access to better health care or housing, means that employment has a rather different social meaning from that in the West. $^{19}$ Consequently, change of employment in Russia could be expected to be especially traumatic. This analysis supports the argument that the rapid pace of change has been an important factor in increasing mortality, with those of working age facing the greatest psychological pressures during the transition to a market economy. Although the youngest and the oldest may have suffered more from material deprivation, they may have been less affected psychologically.

Alcohol-Although this analysis focuses primarily on the underlying rather than the proximal reasons for the decline in life expectancy, it is important to note that the analyses by cause of death strongly support the argument that alcohol has played a major part in the decline in life expectancy in Russia ${ }^{4}$ and show that conditions associated with alcohol consumption, such as accidents, have been even more important in explaining regional differences. The link between accidents and alcohol is well established in many countries but it is also important to note that, in the context of the very high levels of alcohol consumption seen in Russia, ${ }^{20}$ there is now an emerging body of evidence that a substantial proportion of cardiovascular deaths, especially among young men, are due to acute effects of binge drinking. ${ }^{21}{ }^{22}$ This major role for alcohol is not surprising given the position of alcohol in Russian society. There is a long tradition of heavy drinking, encouraged by governments before and after the revolution pursuing policies to recirculate savings by sales of one of the few goods for which supply could meet demand. ${ }^{20}$ Since the late $1980 \mathrm{~s}$ the situation has been exacerbated by extensive illicit trade and prices that have fallen in comparison with those of many other goods. ${ }^{23}$

\section{Summary and implications}

These findings add to the growing literature on the complex relation between wealth, inequalities, and social cohesion, ${ }^{924}$ but, unlike much other work that examines differences between populations at a point in time, this focuses on change, taking advantage of the unique changes in social, economic, and health indicators that occurred in Russia after the break up of the Soviet Union. The health effects of social and economic transition require considerably more research as, although the scale of the transition in Russia is extreme, it is not unique and there is now considerable evidence that the groups affected most in Russia, particularly young men and men in early middle age, have also suffered from the effects of transition elsewhere. ${ }^{25}$ Such effects may also be detectable, albeit on a smaller scale, in other settings, such as parts of western Europe that are becoming de-industrialised. This would be consistent with the literature on the health effects of unemployment and fear of unemployment. ${ }^{26}$

That abrupt socioeconomic change can have adverse effects on population health is not a new idea. Durkheim, in his classic work on suicide published over 100 years ago, concluded that "whenever serious readjustments take place in the social order, whether or not due to a sudden growth or to an unexpected catastrophe, men are more inclined to self destruction.".27 His analysis of anomic suicide placed emphasis on the negative effects of abrupt change and emphasised that it is change rather than any related impoverishment that is critical; this seems extraordinarily prescient in the Russian context. For Durkheim, rapid change results in a temporary disruption of the normal mechanisms through which society imposes limits on behaviour, which in turn results in increased rates of suicide. Although the mortality crisis in Russia has effected many other causes of death in addition to suicide, Durkheim's emphasis on the negative consequences of rapid social and economic change fits well with what we have found with respect to the importance of pace of change in explaining regional variation in mortality trends in Russia. Moreover, the upturn of life expectancy in Russia from 1995 may have also been predicted by Durkheim. He suggested that once some sort of social equilibrium is re-established and individuals are able to reposition themselves in the new social order, self destructive behaviours should decline.

Ways of measuring social cohesion or capital are still being developed, although there is an emerging view that they should include levels of trust, appropriate social organisations, and information channels. ${ }^{29}$ We were unable to measure these directly but there is increasing evidence that crime levels act as a proxy 
Key messages

- The fall in life expectancy in Russia in the 1990s has not affected all parts of the country equally

- The greatest falls have been in some of the wealthiest regions, suggesting that impoverishment is not a sufficient explanation

- Much of the deterioration can be explained by labour force turnover, crime rates (which can be considered a proxy measure of social cohesion), and income inequality

- Alcohol is a major factor in many of the additional deaths

- Understanding changes in mortality in central and eastern Europe during the transition (from a communist to a capitalist system) may shed light on determinants of health in the West

measure. ${ }^{30}$ Our findings strengthen the case for greater research into the ways in which social cohesion can mitigate the effects of social and economic transition.

We thank Judith Shapiro, who provided important insights into the relation between crime and health at an earlier stage of the project, and Sue Gammerman, who ensured the smooth running of the research as project manager.

Contributors: PW proposed initial hypotheses and analysed the data. MM conceived the study, undertook the regression analyses and mapping, and wrote the paper. VS assembled the regional databases, provided expert knowledge of Russian regional differences, and proposed analyses. LC developed the program for the Pollard analysis and provided expert knowledge of the Russian mortality classification. DAL proposed analyses and provided expert knowledge on determinants of mortality. All authors commented on the paper. MM and DL are principal investigators on the larger project of which this study is part. MM is guarantor.

Funding: Department for International Development of the United Kingdom. The department accepts no responsibility for any information provided or views expressed.

Conflict of interest: None.

1 Shkolnikov VM, Nemtsov A. The anti-alcohol campaign and variations in Russian mortality. In: Bobadilla JL, Costello CA, Mitchell F, eds. Premature death in the New Independent States. Washington: National Academy Press, 1997:239-61.

2 Ryan M. Alcoholism and rising mortality in the Russian Federation. BMJ 1995;310:646-8.

3 Shkolnikov V, Meslé F, Vallin J. 1995. La crise sanitaire en Russie. Population 1995; 4-5:907-82.
4 Leon D, Chenet L, Shkolnikov VM, Zakharov S, Shapiro J, Rakhmanova G, et al. Huge variation in Russian mortality rates 1984-1994: artefact, alcohol, or what? Lancet 1997;350:383-8.

5 Cornia GA, Paniccià R. The demographic impact of sudden impoverishment: Eastern Europe during the 1989-94 transition. In: Unicef Innocent Occasional Papers, Economic Policy Studies, No 49. Florence: Unicef, 1995.

6 Jozan PE, Prohorskas R. Atlas of leading and "avoidable" causes of death in countries of central and eastern Europe. Budapest: Hungarian CSO, 1997.

7 Kennedy BP, Kawachi I, Prothrow-Stith D. Income distribution and mortality: cross sectional ecological study of the Robin Hood index in the United States. BMJ 1996;312:1004-7.

8 Shkolnikov VM, Cornia GA. Population crisis and rising mortality in transitional Russia. In: Cornia GA, Paniccia R, eds. The transition's mortality crisis. Oxford: Oxford University Press (in press).

9 Kawachi I, Kennedy BP. Health and social cohesion: why care about income inequality? BMJ 1997;314:1037-40.

10 Treml VG. Soviet and Russian statistics on alcohol consumption and abuse. In: Bobadilla JL, Costello CA, Mitchell F, eds. Premature death in the New Independent States. Washington: National Academy Press, 1997:22038.

11 Pollard JH. The expectation of life and its relationship to mortality.J Inst Actuaries 1982;9:225-40.

12 Anderson BA, Silver BD. Issues of data quality in assessing mortality trends and levels in the newly independent states. In: Bobadilla JL, Costello CA, Mitchell F, eds. Premature death in the New Independent States. Washington: National Academy Press, 1997:120-55.

13 Meslé F, Shkolnikov VM, Hertrich V, Vallin J. Tendances récentes de la mortalité par cause en Russie 1965-1994. Paris: INED, 1996. (Serie: Données Statistiques, No 2.)

14 Service R. A history of twentieth century Russia. London: Penguin, 1997:467.

15 Hajdu P, McKee M, Bojan F. Changes in premature mortality differentials by marital status in Hungary and in England and Wales. Eur J Publ Health 1995;5:259-64.

16 Powell B. Russia: a culture of criminals. Newsweek 1998;131:20-2.

17 Bobak M, Marmot M. East-West mortality divide and its potential explanations: proposed research agenda. BMJ 1996;312:421-5.

18 Shapiro J. Health care policy and Russian health. In: White S, Pravda A, Gitelman Z. Developments in Russian politics. London: Macmillan, 1997.

19 Watson P. Health differences in eastern Europe: preliminary findings from the Nowa Huta study. Soc Sci Med 1998;46:549-58.

20 White S. Russia goes dry. Cambridge: Cambridge University Press, 1996.

21 Chenet L, McKee M, Leon D, Shkolnikov V, Vassin S. Alcohol and cardiovascular mortality in Moscow, new evidence of a causal association.J Epidemiol Community Health (in press).

22 Vikhert AM, Tsiplenkova VG, Cherpachenko NM. Alcoholic cardiomyopathy and sudden cardiac death. J Am Coll Cardiol 1986;8:3-11A.

23 Shapiro J. The Russian mortality crisis and its causes. In: Åslund A, ed. Russian economic reform at risk. London: Pinter, 1995.

24 Wilkinson RG. Unhealthy societies: the afflictions of inequality. London: Routledge, 1996.

25 Chenet L, McKee M, Otero A, Ausin I. What happened to life expectancy in Spain in the 1980s? J Epidemiol Community Health 1997;51:510-4.

26 Jin RL, Shah CP, Svoboda TJ. The impact of unemployment on health: a review of the evidence. Can Med Assoc J 1995;153:529-40.

27 Durkheim E. Suicide: a study in sociology. London: Routledge, 1970.

28 Coleman JS. Foundations of social theory. Cambridge, MA: Harvard University Press, 1990.

29 Putnam RD. Making democracy work. Civic traditions in modern Italy. Princeton: Princeton University Press, 1993.

30 Sampson RJ, Raudenbush SW, Earls F. Neighbourhoods and violent crime: a multilevel study of collective efficacy. Science 1997;277:918-24.

(Accepted 23 April 1998)

\section{Conflict of interest \\ Equanimity upset}

Sir William Osler was characteristically outspoken on conflicts of interest. In Aequinimitas he referred to keeping the practitioner "out of the clutches of the arch enemy of his professional independence- the pernicious literature of our camp followers, a literature increasing in bulk... . The profession has no more insidious foe than the large borderland pharmaceutical houses." ${ }^{1}$ He proposed as an "antidote to the corroding influence of Mammon ... the presence in the community of a body of men devoted to science, living for investigation and caring nothing for the lust of the eyes and the pride of life."

What would he have said about today when many such persons are, to some extent "on the take"? Would he not have concurred with the idea that the blandishments of commerce can predispose an investigator to gratitude? Is it too much to suggest that gratitude, at times a strong feeling, is hardly the stuff of which resisting "the lust of the eyes and the pride of life" is made?

I have always considered Aequinimitas a weapon in keeping the practice of medicine from being tarred with the brush of commerce. Recently, my enthusiasm suffered a reverse when I discovered an inscription in the copy that I own. It reads: "Dear Doctor, We are presenting to you the accompanying volume of addresses by Sir William Osler ... . We hope that, as you read this book, you will appreciate and share Sir William's inspiration, his breadth of vision, and, above all, his persistent search for truth." The signatory, of some 45 years ago, is one of the world's largest pharmaceutical companies.

Joseph Herman, family practitioner, Netivot, Israel

1 Osler W. Aequinimitas. 3rd edition. New York: The Blakiston Company.

We welcome articles up to 600 words on topics such as A memorable patient, A paper that changed my practice, My most unfortunate mistake, or any other piece conveying instruction, pathos, or humour. If possible the article should be supplied on a disk. Permission is needed from the patient or a relative if an identifiable patient is referred to. 